\title{
MUZEUM WYDAWNICTWA SIÓSTR LORETANEK
}

\section{Streszczenie}

W budynku Wydawnictwa Sióstr Loretanek w Warszawie-Rembertowie powstaje muzeum poświęcone pamięci bł. ks. Ignacego Kłopotowskiego. Przygotowywana od kilku lat ekspozycja stała ma popularyzować nie tylko osobę i działalność wydawniczą założyciela Zgromadzenia, ale również promować kulturę słowa drukowanego na bazie prezentowanego zasobu muzealnego. W placówce wyeksponowano postać I. Kłopotowskiego pod kątem jego osobistego zaangażowania $\mathrm{w}$ pracę publicystyczną i drukarską, a także przesłania duchowego, realizowanego w pracy wydawniczej przez zgromadzenie loretanek aż po czasy współczesne. Zwiedzający poznają więc wątek biograficzny w jego społecznym wymiarze, jakim było dzieło ewangelizacji przez słowo drukowane, wspieranie rozwoju czytelnictwa oraz podnoszenie poziomu kulturalnego i oświatowego na tle zmieniających się warunków politycznych. $\mathrm{W}$ muzeum będzie można zobaczyć również warunki techniczne i efekty działalności wydawnictwa w postaci zestawień ekspozycyjnych złożonych z maszyn drukarskich, urządzeń oraz narzędzi specjalistycznych (zecerskich, drukarskich i introligatorskich) czy wybranych egzemplarzy książek i gazet. Ekspozycję wzbogacają nowoczesne pod względem technicznym formy prezentacji danych, które wpływają na urozmaicenie procesu odbioru informacji zawartych w koncepcji muzeum. Muzeum Wydawnictwa Sióstr Loretanek wpisuje się tym samym w aktualny nurt wizualizacji przeszłości historycznej zauważalny w obszarze muzeów kościelnych, w którym eksponaty i materialne pamiątki przeszłości wraz z zastosowanymi rozwiązaniami multimedialnymi współtworzą wartościową pod wieloma względami opowieść. Udostępnienie muzeum szerokiemu gronu odbiorców ubogaci kościelną ofertę muzealną, propagującą zasoby dziedzictwa historycznego Kościoła w zakresie wartości religijnych, duchowych i edukacyjnych.

Słowa kluczowe: Muzeum Wydawnictwa Sióstr Loretanek; ks. Ignacy Kłopotowski; loretanki; Zgromadzenie Sióstr Matki Bożej Loretańskiej

* Joanna Szady - dr hab. historii, Instytut Historii, Katolicki Uniwersytet Lubelski Jana Pawła II; e-mail: joanna.szady@kul.pl

https://orcid.org/0000-0002-6871-5315 
Muzeum Wydawnictwa Sióstr Loretanek związane jest z działalnością publicystyczną bł. ks. Ignacego Kłopotowskiego (1866-1931)1, która obok służby ubogim, była wyrazem jego troski i zaangażowania w życie Kościoła. Wychowanie do ewangelicznej postawy wobec Boga, człowieka i społeczeństwa stało się wyznacznikiem propagowanej przez niego za pośrednictwem słowa drukowanego drogi formacyjnej. Początkowo piśmiennicza aktywność stanowiła element wsparcia dla prowadzonej działalności dobroczynnej², która zintensyfikowała się w latach 1896-1906, kiedy I. Kłopotowski był rektorem kościoła pw. św. Stanisława w Lublinie. Składały się na nią publikacje broszurowe o charakterze teologiczno-moralnym, dewocyjnym, hagiograficznym, historycznym czy polemicznym drukowane w większości w drukarniach warszawskich. Ze względu na przystępną cenę i formę przekazu cieszyły się sporą popularnością wśród prostego ludu i osiągnęły wysokie nakłady ${ }^{3}$. Praca nad pierwszymi publikacjami i ich odbiór społeczny zwrócił uwagę I. Kłopotowskiego na potrzebę zadbania o własną możliwość druku, zwłaszcza wobec planów publikowania czasopism religijnych. Po pierwszej nieudanej próbie uzyskania zgody na wydawanie czasopisma „Praca”4 lepsze warunki do działalności wydawniczej zaistniały dopiero po ogłoszeniu przez władze carskie ukazu tolerancyjnego z 1905 roku. Pojawiła się wtedy możliwość wydawania we własnej drukarni czasopism: „Posiew”, „Polak-Katolik”6

${ }^{1}$ Bł. Ignacy Kłopotowski, ur. 20 lipca 1866 roku w Korzeniówce k. Drohiczyna, zm. 7 września 1931 roku w Warszawie. Pochodził z rodziny z tradycjami patriotycznymi, w której zdobył podstawy edukacji, następnie po ukończeniu Męskiego Gimnazjum Klasycznego w Siedlcach wstąpił do Seminarium Duchownego w Lublinie, naukę i formację kapłańską kontynuował w Akademii Duchownej w Petersburgu. Po przyjęciu święceń kapłańskich w katedrze lubelskiej w 1891 roku pracował m.in. jako: wikariusz parafii Nawrócenia św. Pawła, kapelan szpitala św. Wincentego à Paulo, profesor seminarium lubelskiego i wikariusz katedralny, wspierał liczne dzieła dobroczynne oraz angażował się w pracę wydawniczą; Z.A. Chomiuk CSL, Boży Gwattownik. Stuga Boży ksiądz Ignacy Kłopotowski (1866-1931), w: W duchu i prawdzie. Wybrane sylwetki Kościoła lubelskiego (1805-2005), red. H. Misztal, Lublin 2005, s. 457-460.

${ }^{2} \mathrm{O}$ potrzebie wsparcia inicjatyw dobroczynnych przypominały publikacje I. Kłopotowskiego: Lubelski Dom Zarobkowy, Warszawa 1904 i Przytutek św. Antoniego w Lublinie, Lublin 1906.

${ }^{3}$ J. Styk, Ksiadz Ignacy Klopotowski 1866-1931. Społecznik, publicysta i wydawca, Warszawa 1987, s. 69.

${ }^{4} \mathrm{O}$ stosowne zgody na wydawanie dziennika katolickiego „Praca” I. Kłopotowski starał się bez powodzenia w 1901 roku; Błogosławiony ks. Ignacy Kłopotowski w stużbie ubogim i potrzebujacym, oprac. Z.A. Chomiuk, Warszawa 2005, s. 15-16.

${ }^{5}$ Tygodnik „Posiew” był adresowany do mieszkańców wsi z ukierunkowaniem na edukację religijną i wychowawczo-oświatową przekazywaną w przystępny dla ludu sposób (m.in. w formie gawęd Starego Matusa autorstwa I. Kłopotowskiego). Gazeta propagowała szeroko ujęty program odnowy wsi polskiej włącznie z podnoszeniem kwalifikacji rolniczych; C. Ryszka, Tylko przed Miłościa otwiera się niebo. Błogosławiony ks. Ignacy Kłopotowski (1866-1931), Warszawa 2017, s. 91.

${ }^{6}$ Dziennik „Polak-Katolik” wydawany przez I. Kłopotowskiego w latach 1906-1920 i 19241926 przeznaczony był dla biedniejszych i mniej wykształconych warstw miejskich i wiejskich jako wsparcie ewangelizacyjne, patriotyczne i narodowe; C. Lechicki, Prasa katolicka Drugiej Rzeczypospolitej, „Kwartalnik Historii Prasy Polskiej”, 23 (1984) nr 2, s. 46-47, http://bazhum.muzhp.pl/ autor/Lechicki/Czes\%C5\%82aw/ (dostęp: 30.11.2019). 
oraz „Dobra Stużąca”’ Nowo otwarta placówka (Drukarnia Polaka-Katolika), uzupełniana stopniowo o odpowiednie wyposażenie i fachową siłę roboczą, została w 1908 roku wraz z całą produkcją przeniesiona na większy rynek poligraficzny do Warszawy ${ }^{8}$. Miasto miało już wówczas charakter centrum wydawniczego w Królestwie Polskim. Przed 1905 rokiem ukazywała się tu ponad połowa (27) z 49 publikowanych ówcześnie periodyków katolickich ${ }^{9}$. Po okresie korzystania z wynajętych lokali drukarnia znalazła w latach 1913-1926 stałą siedzibę przy ul. Krakowskie Przedmieście 71 ${ }^{10}$. W 1927 roku ks. I. Kłopotowski zakupił drukarnię na potrzeby dalszej własnej działalności wydawniczej przy ul. Tamka 46 i zarejestrował pod nazwą Drukarnia Loretańska pod zarządem Sióstr Loretanek ${ }^{11}$. Pracę bieżącą drukarni utrudniał fakt podziału na część produkcyjną (ul. Tamka) oraz wydawniczą i administracyjną (ul. Miodowa). Połączenie wszystkich czynności poligraficznych było możliwe dopiero po przeniesieniu Drukarni Loretańskiej w 1931 roku do zabudowań po dawnej fabryce koronek i firanek przy ul. Namiestnikowskiej 6 (obecnie ul. Józefa Sierakowskiego). Na mocy zapisu testamentalnego drukarnia przeszła po śmierci założyciela na własność Sióstr Loretanek i do 1992 roku funkcjonowała na warszawskiej Pradze. Liczne zmiany lokalizacji drukarni nie przeszkadzały w kontynuacji prowadzonego dzieła wydawniczego. Zgodnie $\mathrm{z}$ duchowym przesłaniem Założyciela „książka jest chlebem dla duszy" - kolejno otwierane placówki drukarskie i sieć księgarń ${ }^{12}$ założonych przez ks. I. Kłopotowskiego pełniły zadania ewangelizacji słowem drukowanym, zgodnie z nurtem zaangażowania Kościoła w zadania duszpasterskie za pomocą środków masowego przekazu. Szczególne znaczenie zaczęto przypisywać wtedy czasopismom, które pozwalały na systematyczne przekazywanie treści religijnych odbiorcom z różnych obszarów środowiskowych. Adresatami publikacji byli przede wszystkim przedstawiciele grup społecznych o największym stopniu

${ }^{7}$ Miesięcznik „Dobra Służąca” (kontynuowany przez innych wydawców jako „Pracownica Polska” lub „Pracownica Katolicka”) był pismem przeznaczonym początkowo dla żeńskiej służby domowej, a z czasem - dla wszystkich kobiet pracujących zawodowo; Styk, Ksiądz Ignacy Kłopotowski, s. 165-167.

${ }^{8}$ Drukarnia I. Kłopotowskiego działała w okresie lubelskim pod adresami: Krakowskie Przedmieście 46, Królewska 10, a w początkowym okresie warszawskim: Piękna 1, Trębacka 11, Krakowskie Przedmieście 64; A. Adamski, Kapłan i dziennikarz. Błogosławiony ks. Ignacy Kłopotowski (1866-1931), Warszawa 2008, s. 48-49.

${ }^{9}$ A. Boruc, Geografia $i$ działalność wydawnictw katolickich $w$ Królestwie Polskim $w$ drugiej połowie XIX i na poczatku XX wieku, „Colloquia Litteraria UKSW”, (2013) nr 2/15, s. 88, http://bazhum.muzhp.pl/media//files/Colloquia_Litteraria/Colloquia_Litteraria-r2013-t2-n15/Colloquia_Litteraria-r2013-t2-n15-s87-107/Colloquia_Litteraria-r2013-t2-n15-s87-107.pdf (dostęp: 20.11.2019).

${ }^{10}$ Dom redakcyjny wraz z drukarnią i księgarnią ks. I. Kłopotowski przekazał na własność archidiecezji warszawskiej.

${ }^{11}$ Zgromadzenie Sióstr Matki Bożej Loretańskiej założone przez ks. I. Kłopotowskiego w 1920 roku specjalnie dla celów apostolstwa słowem drukowanym; B. Łoziński, Leksykon zakonów w Polsce. Informator o życiu konsekrowanym, Warszawa 1998, s. 244.

${ }^{12}$ Księgarnie powstały m.in. w Siedlcach, Łodzi i Warszawie, D. Olszewski, Ks. Ignacy Kłopotowski. Życie i apostolat, Warszawa 1996, s. 58. 
zaniedbania edukacyjnego, którym lektura religijna miała dostarczyć treści podnoszących poziom kulturalny i oświatowy. Wraz rozwojem własnych możliwości drukarskich poszerzała się także oferta wydawnicza podejmowana przez ks. I. Kłopotowskiego, szczególnie w zakresie czasopiśmiennictwa. Szeroki zasięg społecznego oddziaływania periodyków umożliwiał zarówno system prenumeraty i bezpłatnego kolportażu zastosowany przez loretanki, jak i wspólnej lektury domowej czytelników. Na sukces wydawniczych inicjatyw ks. I. Kłopotowskiego złożyło się nie tylko wyczucie potrzeb społecznych w zakresie czytelnictwa, odpowiedni dobór treści i form przekazu, ale i współdzielenie zadań poligraficznych z siostrami loretankami, zgodnie z przypisanym im apostolatem słowa drukowanego. Stopniowe nabywanie umiejętności fachowych w praktycznej pracy zecerskiej i introligatorskiej wiązało się ściśle z posłannictwem zgromadzenia i jego służbą na rzecz dobrej prasy. Warto podkreślić przy tym, że główny charakter zgromadzenia związany z pracą wydawniczą pozostawał wyjątkowy na tle nurtu wychowawczo-opiekuńczego, jaki w przeważającej większości reprezentowały w tym okresie żeńskie zgromadzenia zakonne ${ }^{13}$.

Lokalizacja muzeum w budynku Wydawnictwa Sióstr Loretanek ${ }^{14}$ w bezpośredni sposób nawiązuje do dziedzictwa pracy wydawniczej i redakcyjnej ks. I. Kłopotowskiego oraz powołanego w tym celu zgromadzenia zakonnego. $\mathrm{Na}$ potrzeby ekspozycji wystawienniczej zaaranżowano fragment zabudowań $\mathrm{w}$ formie wieży przy kaplicy zakonnej, co przynosi swoistego rodzaju konsekwencje w zakresie organizacji muzeum. Zastosowano tu amfiladowy układ pomieszczeń zwiedzanych $\mathrm{w}$ pionie, a nie - jak to ma zazwyczaj miejsce $\mathrm{w}$ takich przypadkach - w poziomie. Przestrzeń muzealna obejmuje dwie tzw. sale główne oraz klatkę schodową z platformami na półpiętrach, przy czym zauważalna jest maksymalna efektywność jej aranżacji ${ }^{15}$. Odbiór wrażeniowy podkreślono dodatkowo pastelową kompozycją barw, grą świateł, zróżnicowaną formą prezentacji danych (eksponaty i projekcje multimedialne ${ }^{16}$ ), zabiegami powiększającymi optycznie przestrzeń (portrety wielkoformatowe i witrażowe) czy skupiającymi uwagę na wybranych detalach (kształt i forma gablot, ustawienie sprzętów i bibelotów). Planowany kierunek zwiedzania odzwierciedla przyjęty w muzeum układ chronologiczno-problemowy treści wystawienniczych. Są nimi wzajemnie przeplatające się wątki: biograficzny bł. ks. I. Kłopotowskiego i tematyczny, związany z rozwojem wydawnictwa, których zwieńczeniem jest współczesna kontynuacja jego historycznej spuścizny. Są one ze sobą na tyle nierozerwalnie złączone, że przewijają się w zakresie prezentowanych treści muzealnych zarówno w odniesieniu

${ }^{13}$ Inicjatywy wydawnicze sióstr (sercanki, klawerianki) należały w odrodzonym państwie polskim do wyjątków; Olszewski, Ks. Ignacy Kłopotowski, s. 103.

${ }^{14}$ Wydawnictwo Sióstr Loretanek od 1993 roku mieści się przy ul. L. Żeligowskiego 16/20 w Warszawie (Rembertów).

${ }^{15}$ Ze względu na częściowe rozmieszczenie ekspozycji w przestrzeni klatki schodowej zwiedzanie może odbywać się w niewielkich grupach.

${ }^{16}$ Elementy wyposażenia multimedialnego na cele muzealne zostały dofinansowane ze środków Ministra Kultury i Dziedzictwa Narodowego pochodzących z Funduszu Promocji Kultury w 2018 roku; Zgromadzenie Sióstr Matki Bożej Loretańskiej. Projekty - wspótpraca, http://www. loretanki.pl/Projekty (dostęp: 21.11.2019). 
do życia bł. ks. I. Kłopotowskiego i jego bezpośredniego zaangażowania w dzieło wydawnicze (do 1931 roku), jak i okresu późniejszego, kiedy druk publikacji religijnych kontynuowało założone przez niego zgromadzenie. Kierunek zwiedzania w górę wiedzie grupę oglądających nie tylko ścieżką historyczną, ale i duchową aż do świętości życia na wzór postaci błogosławionego. Motywem przewodnim po zróżnicowanych treściach wystawy jest oś czasu łącząca etapy życia ks. I. Kłopotowskiego z prowadzoną przez niego pracą na rzecz propagowania piśmiennictwa religijnego $\mathrm{w}$ formie książek, broszur i czasopism. Przyjmuje ona postać plansz informacyjnych prezentowanych w systemie linkowym, które poprzez jednolitą i powtarzalną formę stanowią wyznacznik kierunku zwiedzania, a ze względu na zawarte treści dzielą proces oglądu wystawy na poszczególne działy czasowotematyczne. Są nimi: początki działalności wydawniczej, rozwój wydawnictwa za życia założyciela, kontynuacja pracy wydawniczej po jego śmierci, zmiany lokalizacji drukarni, ewolucja techniki drukarskiej, praca wydawnicza w okolicznościach cenzury aż po prowadzenie swobodnej działalności wydawniczej po zmianach politycznych 1989 roku. Szczególne miejsce zajmuje w muzeum temat procesu beatyfikacyjnego założyciela i uwypuklenie apostolstwa słowa drukowanego jako misji zgromadzenia realizowanej nieprzerwanie od blisko 100 lat. W obliczu tradycji pracy wydawniczej i świętości życia ks. I. Kłopotowskiego wyjątkowego znaczenia nabiera prezentacja aktualnego wymiaru funkcjonowania Wydawnictwa Sióstr Loretanek jako materialnego i duchowego dzieła na rzecz ewangelizacji, które pozostaje otwarte na potrzeby współczesnego odbiorcy.

Opowieść narracyjną o wydawnictwie otwiera ekspozycja muzealna w pierwszej z dwóch głównych sal muzealnych. W sali redakcyjnej założyciela zwiedzający może zapoznać się w przystępny sposób z postacią ks. I. Kłopotowskiego, zaprezentowaną w kontekście jego aktywności zawodowej jako autora, redaktora i wydawcy. Sprzyja temu rekonstrukcja gabinetu błogosławionego, w tym elementów umeblowania, przedmiotów osobistego użytku, bibelotów, książek, obrazów czy fotografii. Zwiedzający mogą zobaczyć biurko, biblioteczkę i sekretarzyki ks. I. Kłopotowskiego udekorowane przedmiotami wspomagającymi własną pracę pisarską i organizującą proces wydawniczy, m.in.: maszynę do pisania, pióro i kałamarz, pieczątki, aparat telefoniczny. Umiejętnie dobrane elementy wyposażenia wskazują na szerszy kontekst biograficzny (pochodzenie, wykształcenie, powołanie, droga posługi kapłańskiej), który służy uzupełnieniu głównego wątku działalności redakcyjnej. Tworzy go zestaw fotografii, portretów, map, rycin, książek oraz przedmiotów kultu. Pokój redakcyjny stanowi wprowadzenie do całej ekspozycji muzealnej, nie tylko poprzez prezentację postaci założyciela wydawnictwa, ale również dzięki nasyceniu przestrzeni sali wytworami pracy redakcyjno-wydawniczej (produkcja piśmiennicza wydawnictwa) i oddaniem atmosfery księgarsko-bibliotecznej (zabytkowy księgozbiór podręczny). Ten element wystawy przekazany jest w tradycyjnej formie gablotowej, w której wyeksponowano różnorodne wydawnictwa broszurowe ${ }^{17}$, a także wyróżniające się pod

${ }^{17} \mathrm{~W}$ tym m.in. pierwsza publikacja autorska z 1896 roku pt. Nawiedzenia Najświętszego Sakramentu, która zainicjowała działalność publicystyczną; ABC życia chrześcijańskiego wedtug ks. Ignacego Kłopotowskiego, oprac. K. Bielecka CSL, Warszawa 2005, s. 8. 
względem oprawy i ozdobnej formy książki własne. W gablocie ściennej są prezentowane przykładowe numery czasopism: miesięcznik „Kółko Różańcowe” tygodnik „Anioł Stróż”"19, tygodnik „Przegląd Katolicki”" płański” ${ }^{21}$ oraz wspomniane wyżej czasopisma „Polak-Katolik” i „Posiew” (wraz z dodatkiem „Słowo Boże”22). Uzupełnieniem statycznego sposobu prezentacji są w tej części wystawy ekrany dotykowe, które pozwalają na wgląd do wybranych pozycji piśmienniczych zabezpieczonych w gablotach. Dzięki technice przesuwnego obrazu zwiedzający mogą oglądać w formie multimedialnej zawartość pierwszych numerów czasopism religijnych, które ukazywały się nakładem wydawnictwa oraz szczególnie cennych pozycji z księgozbioru prywatnego.

Przedłużeniem tematycznym sali gabinetowej jest dalszy ciąg wystawy muzealnej w poziomo-pionowym układzie kolejnych pomieszczeń. Uwagę odbiorcy zwracają tu nawiązania do aspektu wydawniczego poprzez wyeksponowanie materialnych pamiątek z produkcji piśmienniczej. Składają się na nie dwie prezentacje: zestaw zabytkowych czcionek drukarskich z drewna o różnych kształtach i rozmiarach oraz ekspozycja zecerska złożona $\mathrm{z}$ ważniejszych dat $\mathrm{z}$ biografii ks. I. Kłopotowskiego ${ }^{23}$. W tej części wystawy dominuje słowo drukowane w różnorodnych formach wydawniczych, jakie wychodziły spod maszyn drukarskich na przestrzeni lat. Starano się tu zestawić zasoby piśmiennicze z uwzględnieniem zróżnicowanego formatu, oprawy czy szaty graficznej, tak aby przekazać dynamikę zmian w technice drukarskiej od XIX wieku po współczesność. Obok przykładów książek wydanych przez Wydawnictwo Sióstr Loretanek, które na stałe weszły do kanonu literatury religijnej, wyeksponowano też zbiór przykładowych numerów czasopism. Nasycona różnorodnymi pod względem kształtu i kolorystyki woluminami przestrzeń wystawiennicza jest doskonałym wprowadzeniem do problematyki pracowni wydawniczej zorganizowanej $\mathrm{w}$ drugiej $\mathrm{z}$ dwóch głównych sal muzeum. Zwiedzający poznają w niej historyczne aspekty funkcjonowania wydawnictwa, w skład którego wchodziła praca zecerska, drukarska i introligatorska. Prezentowane są w niej oryginalne maszyny specjalistyczne

${ }^{18}$ Wydawane od 1909 roku czasopismo dla bractw i kółek Żywego Różańca, które obok treści formacyjnych niosło przekaz popularyzacji modlitwy różańcowej i formacji duchowej, opierając się na jej kultywowaniu; Olszewski, Ks. Ignacy Kłopotowski, s. 81-82.

${ }^{19}$ Tygodnik powstały z inspiracji I. Kłopotowskiego dla dzieci wiejskich, najbardziej narażonych na brak dostępu do szkolnictwa i oświaty, który ukazywał się w 1. 1911-1919 i ponownie od 1926 roku (jako nowa inicjatywa wydawnicza); Styk, Ksiadz Ignacy Klopotowski, s. 179.

${ }^{20}$ Redagowany i wydawany przez I. Kłopotowskiego w Drukarni Polaka Katolika w latach 1922-1926, wznowiony po wieloletniej przerwie jako czasopismo dla kapłanów i warstwy inteligenckiej; Bibliografia katolickich czasopism religijnych $w$ Polsce 1918-1939, oprac. i red. Z. Zieliński, Lublin 1981, s. 236.

${ }^{21}$ Czasopismo formacyjne dla duchowieństwa redagowane okresowo przez I. Kłopotowskiego i wydawane w Drukarni Loretańskiej w latach 1927-1939; Bibliografia, s. 111.

${ }^{22}$ Dodatek zawierający fragment Ewangelii na niedzielę, homilię i teksty dewocyjne oraz hagiograficzne; Adamski, Kapłan i dziennikarz, s. 63.

${ }^{23}$ Ten fragment ekspozycji ma zostać uzupełniony jeszcze o motyw lustrzanego odbicia słów na ścianie, tak aby były czytelne dla wszystkich zwiedzających; relacja s. Stefanii Korbuszewskiej CSL z 20 listopada 2019 roku. 
zakupione przez ks. I. Kłopotowskiego do produkcji książek i czasopism: maszyny drukarskie (manualne i elektryczne), prasy czy gilotyna drukarska. W sali tej znajdziemy też dodatkowe elementy wyposażenia $\mathrm{w}$ postaci pomocniczych narzędzi drukarskich, czcionek, matryc, ozdobników, kaszt zecerskich czy szuflad ze składem drukarskim. Kontakt z takimi oryginalnymi eksponatami muzealnymi nie tylko zapewnia zwiedzającym efektywniejszy przekaz treściowy o technice dawnego drukarstwa, ale przede wszystkim uzmysławia, jakiego dużego wysiłku fizycznego wymagała ta praca. Działalność wydawniczą loretanek wizualizują dodatkowo fotografie ze scenami z obsługi poszczególnych maszyn i narzędzi drukarskich oraz projekcja filmu dokumentującego pracę w drukarni ${ }^{24}$. Atrakcją tej części wystawy jest niewątpliwie elektroniczna kaszta zecerska, która pozwala na zredagowanie własnego tekstu złożonego z zestawu trójwymiarowych czcionek. Wymaga to cierpliwości, precyzji i wyobraźni w posługiwaniu się multimedialnym materiałem skonstruowanym $\mathrm{w}$ formie lustrzanego odbicia. Zabawa w zestawianie słów i zdań pozwala na wejście w fachową rolę zecera i uzyskanie pamiątki z wycieczki do muzeum w postaci wydruku własnej pracy. Uzupełnieniem wizualizacji dawnej techniki drukarsko-wydawniczej jest też pracownia montażu ręcznego ze zbiorem dawnych sprzętów i narzędzi oraz różnorodnych elementów niezbędnych w procesie wydawniczym, takich jak: urządzenia introligatorskie, maszyny do pisania, pieczątki, tusze, taśmy kopiujące czy próbki prac drukarskich. Za pomocą ekranu dotykowego istnieje też możliwość wglądu do bazy wszystkich wydanych przez wydawnictwo książek. Oglądając zeskanowane kopie okładek książkowych, zwiedzający mają przy okazji możliwość zapoznania się z procesem zmian $\mathrm{w}$ technice drukarskiej i jednocześnie porównania estetyki szaty graficznej na przestrzeni XIX i XXI wieku.

Podsumowaniem wieloletniej działalności wydawnictwa jest prezentacja jego współczesnej formy i szerokiego zakresu działania w przestrzeni medialnej. Dzieło wydawnicze realizowane jest aktualnie w sieci placówek wydawniczych w kraju i za granicą, w tym we Włoszech, Rumunii i na Ukrainie ${ }^{25}$. Przesłanie apostolatu ducha i umysłu sióstr loretanek zawarte jest w formie cytatów z wypowiedzi ks. I. Kłopotowskiego rozmieszczonych na ścianach sal muzealnych. Przypominają one o społecznej potrzebie ewangelizacji za pośrednictwem słowa drukowanego i propagowania wartości religijno-duchowych, jakie w ten sposób docierały i wciąż powinny docierać do czytelnika. Obecnie przy wydawaniu kilkudziesięciu pozycji książkowych rocznie korzysta się $\mathrm{w}$ tym celu zarówno $\mathrm{z}$ doświadczenia zawodowego, jak i z nowoczesnych metod pracy drukarskiej ${ }^{26}$. Oferta wydawnicza obejmuje publikacje przeznaczone do odbiorcy w różnym wieku (dzieci, młodzież, dorośli) i o zróżnicowanych oczekiwaniach formacyjnych. Wydawnic-

${ }^{24}$ Projekcja czarno-białego filmu $\mathrm{z}$ lat 80 . XX wieku ma zostać uzupełniona o filmową opowieść o współczesnej pracy wydawniczo-drukarskiej sióstr; relacja s. Stefanii Korbuszewskiej CSL z 20 listopada 2019 roku.

${ }^{25}$ Ostatnia część ekspozycji muzealnej z zakresu aktualnej oferty wydawniczej pozostaje jeszcze na etapie dopracowania; relacja s. Stefanii Korbuszewskiej CSL z 20 listopada 2019 roku.

${ }^{26}$ Zgromadzenie Sióstr Matki Bożej Loretańskiej. Wydawnictwo Sióstr Loretanek - Warszawa Rembertów, http://www.loretanki.pl/Wydawnictwo-Siostr-Loretanek (dostęp: 21.11.2019). 
two Sióstr Loretanek oferuje wiele wartościowych pozycji czytelniczych, w tym: modlitewniki, książki pogłębiające duchowość maryjną i biblijną, poradniki umacniające życie rodzinne, małżeńskie, wyjaśniające także dylematy wychowawcze oraz publikacje o tematyce historyczno-społecznej ${ }^{27}$. Dzięki wyrobom poligraficznym loretanek można się również zaopatrzyć $\mathrm{w}$ wiele produktów akcydensowych, takich jak: portrety, plakaty, obrazki, zeszyty, zakładki do książek, kartki pocztowe, foldery, papeterie, kalendarze czy dewocjonalia. Systematyczny kontakt z lekturą religijną zapewniają również wydawane aktualnie miesięczniki: „Różaniec”, „Tak Rodzinie” oraz „Anioł Stróż”.

Powstanie Muzeum Wydawnictwa Sióstr Loretanek wpisuje się w zauważalny aktualnie nurt rozwoju i unowocześniania muzealnych ekspozycji kościelnych. Efektowny pod wieloma względami sposób prezentacji zasobu muzealnego loretanek świadczy nie tylko o stopniowym polepszaniu oferty wystawienniczej przy placówkach kościelnych, ale i wychodzi naprzeciw niekorzystnej oceny sytuacji w tym typie muzealnictwa pod względem zastosowania nowoczesnych rozwiązań ${ }^{28}$. Trzeba przy tym podkreślić, że proces zmian, jakimi podlegają muzea kościelne, przebiega niezależnie od utrudnień natury prawno-finansowej czy specjalistycznych rozwiązań systemowych, które omijały niejednokrotnie takie instytucje. Przede wszystkim kwestię zasobów muzealnych włączono w obręb zintegrowanych działań Kościoła na rzecz zabezpieczenia dziedzictwa materialnego i duchowego w połączeniu z oddziaływaniem duszpasterskim. Ukierunkowanie muzeów kościelnych na funkcję pastoralną stało się od 2001 roku niewątpliwie wyznacznikiem nowego modelu takiej placówki $\mathrm{i}^{29}$. W ochronę i promocję dziedzictwa kulturowego w postaci oryginalnie urządzanych przestrzeni wystawienniczych włączyły się również żeńskie zgromadzenia zakonne. W ostatnich latach nowoczesne pod względem koncepcji merytorycznej i technologicznej ekspozycje muzealne powstały m.in. u sióstr albertynek ${ }^{30}$, karmelitanek ${ }^{31}$, sióstr Matki

${ }^{27}$ M. Laskowska, Apostolat ducha i umystu, https://adonai.pl/kultura/?id=25(dostęp: 21.11.2019).

${ }^{28}$ N.W. Błażejczyk CSSF, Międzynarodowa konferencja „, Muzea kościelne wobec nowych wyzwań”, Mszczonów, 18-20 października 2017 rok, „Archiwa Biblioteki i Muzea Kościelne”, 110 (2018) s. 535.

${ }^{29}$ A. Rusak, Aktualność pastoralnej i dydaktycznej roli polskich muzeów i skarbców kościelnych, w: Muzeum kościelne w perspektywie zadań i trendów wspótczesnego muzealnictwa. Materiały $z$ sesji naukowej $w$ dniach 14-15 czerwca 2012 r., red. T. Dudek-Bujarek, Katowice 2013, s. 33; B. Skrzydlewska, Problemy $i$ wyzwania muzealnictwa kościelnego w Polsce. Historia $i$ wspótczesność, w: Muzea kościelne wobec nowych wyzwań, red. N.W. Błażejczyk, P. Majewski, Warszawa 2019, s. 141, https://www.nimoz.pl/files/publications/61/Muzea\%20ko\%C5\%9Bcielne\%20internet. pdf (dostęp: 20.11.2019).

${ }^{30}$ Muzeum św. Alberta w Igołomi, http://www.igwa.pl/art,662,muzeum-sw-alberta-w-igolomi (dostęp: 30.11.2019)

${ }^{31}$ Muzeum Domu Macierzystego Zgromadzenia Sióstr Karmelitanek Dzieciatka Jezus w Sosnowcu, https://www.karmelitanki.pl/muzeum/ (dostęp: 30.11.2019). 
Bożej Miłosierdzia ${ }^{32}$, sióstr Rodziny Maryi ${ }^{33}$, a w trakcie realizacji jest aktualnie projekt inwestycyjny Wirydarze dziedzictwa benedyktyńskiego w Staniątkach ${ }^{34}$.

Dzięki zastosowaniu różnorodnych form przekazu, ekspozycja loretanek spełnia oczekiwania wymagającego współczesnego odbiorcy, nastawionego na wielowymiarowy przekaz treści w zróżnicowanej scenerii oraz w formach wywołujących interakcje. Zapewniają je zróżnicowane techniki wystawiennicze wsparte rozwiązaniami multimedialnymi, dzięki którym dostępne jest szerokie spektrum aktywności - od poznania treści i kształtowania umiejętności docierania do wiedzy, poprzez czynności kreacyjne i partycypacyjne w jej odkrywaniu - aż po odniesienia do poziomu wychowawczego. Taka konstrukcja wnętrza pozostaje w konwencji muzeum nowego typu, w którym zainteresowanie publiczności osiąga się poprzez odpowiednie strategie przekazu i eksponowania danych ${ }^{35}$. Jednocześnie muzeum loretanek zachowuje wyważone proporcje pomiędzy tradycją a nowoczesnością, a oryginalny zestaw danych nie klasyfikuje go jednoznacznie jako muzeum zakonnego, biograficznego czy izby drukarstwa. Muzeum Wydawnictwa Sióstr Loretanek w efektywny sposób może przekazywać zróżnicowane treści historyczne związane z postacią bł. ks. Ignacego Kłopotowskiego - założyciela Zgromadzenia Loretanek wraz z jego wkładem w powstanie i rozwój wydawnictwa. Zapoznaje też z tajnikami techniki drukarskiej i technologicznym postępem w dziedzinie poligrafii. Dzięki nasyceniu przestrzeni wystawienniczej książkami i czasopismami propaguje kulturę słowa drukowanego i wskazuje na korzyści, jakie niesie wartościowa lektura książki i prasy. Muzeum jest też świadectwem rozwoju katolickiej produkcji wydawniczej dla potrzeb ewangelizacyjnych, ale i informacyjnych czy edukacyjno-wychowawczych. Muzealna opowieść nie skupia się na żadnym $z$ wątków tematycznych, ale łączy je w spójną całość zgodnie z koncepcją muzeum narracyjnego, działającego na zasadzie współprzeżywania opowiadanej historii i wykorzystującego materialne cechy obiektów ${ }^{36}$. Planowane na 2020 rok otwarcie muzeum uświetni z całą pewnością cykl obchodów rocznicowych, jakie trwają w Zgromadzeniu Sióstr Loretanek od 2016 roku, przyczyniając się do przywrócenia pamięci o postaci bł. ks. I. Kłopotowskiego i jego zasługach na polu działalności społecznej w XIX i XX wieku.

${ }^{32}$ Muzeum Zgromadzenia Sióstr Matki Bożej Miłosierdzia, https://www.faustyna.pl/zmbm/ 4-muzeum-zgromadzenia-siostr-matki-bozej-milosierdzia-muzeum/ (dostęp: 30.11.2919).

${ }^{33}$ Muzeum św. Zygmunta Felińskiego, http://muzeumfelinskiego.pl/p1/ (dostęp: 30.11.2019).

${ }^{34}$ Wirydarze dziedzictwa benedyktyńskiego, https://www.benedyktynki.eu/opactwo1/wirydarze/ (dostęp: 30.11.2019).

${ }^{35}$ A. Ziębińska-Witek, G. Żuk, Wprowadzenie, w: Muzea w kulturze wspótczesnej, red. A. Ziębińska-Witek, G. Żuk, Lublin 2015, s. 11; K.A. Gajda, Edukacyjna rola muzeum, Kraków 2019, s. 33 .

${ }^{36}$ B. Kłaput, Pomiędzy Scylla a Charybda. Muzeum narracyjne oczyma projektantów, w: Muzeum i zmiana. Losy muzeów narracyjnych, red. P. Kowal, K. Wolska-Pabian, Warszawa-Kraków 2019, s. 303; A. Ziębińska-Witek, Renesans materialności, czyli o powrót obiektów do muzeum, w: Historia - dziś. Teoretyczne problemy wiedzy o przeszłości, red. E. Domańska, R. Stobiecki, T. Wiślicz, Kraków 2015, s. 223. 


\section{BIBLIOGRAFIA}

\section{Opracowania}

ABC życia chrześcijańskiego wedtug ks. Ignacego Kłopotowskiego, oprac. K. Bielecka CSL, Warszawa 2005.

Adamski Andrzej, Kapłan i dziennikarz. Błogosławiony ks. Ignacy Kłopotowski (18661931), Warszawa 2008.

Bibliografia katolickich czasopism religijnych $w$ Polsce 1918-1939, oprac. i red. Z. Zieliński, Lublin 1981.

Błażejczyk Natanaela Wiesława CSSF, Międzynarodowa konferencja „,Muzea kościelne wobec nowych wyzwań”. Mszczonów, 18-20 października 2017 rok, „Archiwa, Biblioteki i Muzea Kościelne”, 110 (2018), s. 529-537.

Błogosławiony ks. Ignacy Kłopotowski w stużbie ubogim i potrzebujacym, oprac. Z.A. Chomiuk, Warszawa 2005.

Boruc Alicja, Geografia i działalność wydawnictw katolickich w Królestwie Polskim $w$ drugiej połowie XIX i na poczatku XX wieku, „Colloquia Litteraria UKSW”, (2013) nr 2/15, s. 87-107.

Chomiuk Zofia Alina CSL, Boży Gwałtownik. Stuga Boży ksiądz Ignacy Kłopotowski (1866-1931), w: W duchu i prawdzie. Wybrane sylwetki Kościoła lubelskiego (18052005), red. H. Misztal, Lublin 2005, s. 457-463.

Gajda Kinga Anna, Edukacyjna rola muzeum, Kraków 2019.

Kłaput Barbara, Pomiędzy Scylla a Charybda. Muzeum narracyjne oczyma projektantów, w: Muzeum i zmiana. Losy muzeów narracyjnych, red. P. Kowal, K. Wolska-Pabian, Warszawa-Kraków 2019, s. 301-317.

Kłopotowski Ignacy, Przytułek św. Antoniego w Lublinie, Lublin 1906.

Lechicki Czesław, Prasa katolicka Drugiej Rzeczypospolitej, „Kwartalnik Historii Prasy Polskiej", 23 (1984), nr 2, s. 46-47.

Lubelski Dom Zarobkowy, wyd. Ignacy Kłopotowski, Warszawa 1904.

Łoziński Bogumił, Leksykon zakonów w Polsce. Informator o życiu konsekrowanym, Warszawa 1998.

Olszewski Daniel, Ks. Ignacy Kłopotowski. Życie i apostolat, Warszawa 1996.

Rusak Andrzej, Aktualność pastoralnej i dydaktycznej roli polskich muzeów i skarbców kościelnych, w: Muzeum kościelne $w$ perspektywie zadań i trendów współczesnego muzealnictwa. Materiały z sesji naukowej w dniach 14-15 czerwca 2012 r., red. T. Dudek-Bujarek, Katowice 2013, s. 31-38.

Ryszka Czesław, Tylko przed Miłościa otwiera się niebo. Błogosławiony ks. Ignacy Kłopotowski (1866-1931), Warszawa 2017.

Styk Józef, Ksiadz Ignacy Kłopotowski 1866-1931. Społecznik, publicysta $i$ wydawca, Warszawa 1987.

Ziebińska-Witek Anna, Renesans materialności, czyli o powrót obiektów do muzeum, w: Historia - dziś. Teoretyczne problemy wiedzy o przeszłości, red. E. Domańska, R. Stobiecki, T. Wiślicz, Kraków 2015, s. 217-228.

Ziębińska-Witek Anna, Żuk Grzegorz (red.), Wprowadzenie, w: Muzea w kulturze wspótczesnej, Lublin 2015, s. 7-18.

\section{Netografia}

Laskowska Małgorzata, Apostolat ducha i umystu, https://adonai.pl/kultura/?id=25 (dostęp: 21.11.2019). 
Skrzydlewska Beata, Problemy $i$ wyzwania muzealnictwa kościelnego w Polsce. Historia $i$ współczesność, w: Muzea kościelne wobec nowych wyzwań, red. N.W. Błażejczyk, P. Majewski, Warszawa 2019, s. 133-146, https:/www.nimoz.pl/files/publications/61/ Muzea\%20ko\%C5\%9Bcielne\%20internet.pdf (dostęp: 20.11.2019).

Zgromadzenie Sióstr Matki Bożej Loretańskiej. Projekty - wspótpraca, http://www.loretanki.pl/Projekty (dostęp: 21.11.2019).

Zgromadzenie Sióstr Matki Bożej Loretańskiej. Wydawnictwo Sióstr Loretanek - Warszawa Rembertów, http://www.loretanki.pl/Wydawnictwo-Siostr-Loretanek (dostęp: 21.11.2019).

Muzeum św. Alberta w Igołomi, http://www.igwa.pl/art,662,muzeum-sw-alberta-w-igolomi (dostęp: 30.11.2019).

Muzeum Domu Macierzystego Zgromadzenia Sióstr Karmelitanek Dzieciątka Jezus w Sosnowcu, https://www.karmelitanki.pl/muzeum/ (dostęp: 30.11.2019).

Muzeum Zgromadzenia Sióstr Matki Bożej Miłosierdzia, https://www.faustyna.pl/zmbm/4-muzeum-zgromadzenia-siostr-matki-bozej-milosierdzia-muzeum/ (dostęp: 30.11.2919).

Muzeum św. Zygmunta Felińskiego, http://muzeumfelinskiego.pl/pl/ (dostęp: 30.11.2019)

Wirydarze dziedzictwa benedyktyńskiego, https://www.benedyktynki.eu/opactwo1/wirydarze/ (dostęp: 30.11.2019).

\section{Relacja}

Relacja s. Stefanii Korbuszewskiej CSL z 20 listopada 2019 roku. 
MUSEUM OF THE LORETO SISTERS' PUBLISHING HOUSE

\section{Summary}

A museum devoted to the memory of Blessed Rev. Ignacy Kłopotowski is being built in the building of the Loreto Sisters' Publishing House in Warszawa-Rembertów. The permanent exhibition, which has been prepared for several years, is to popularize not only the above mentioned figure and the publishing activity of the founder of the Congregation, but also to promote the culture of printed word on the basis of the presented museum's resources. The figure of I. Kłopotowski was exposed in the museum in terms of his personal involvement in journalistic and printing work, as well as his spiritual message, which has been realized in publishing work by the congregation of the Loreto Sisters up to the present day. In this way, visitors will learn about the biographical theme in its social dimension, which was a work of evangelization through the printed word, promotion of reading habits and raising the cultural and educational level in light of changing political conditions. The museum will also offer an opportunity to see the technical conditions and effects of the publishing house's activities in the form of exhibition sets consisting of printing machines, equipment and specialist (typesetting, printing and bookbinding) tools or selected copies of books and newspapers. The exhibition is enriched by technically modern forms of data presentation, which diversify the process of reception of information contained in the museum concept. The Museum of the Loreto Sisters' Publishing House thus fits into the current trend of visualizing the historical past, which is noticeable in the area of church museums, where the exhibits and material souvenirs of the past together with the applied multimedia solutions create a story that is valuable in many respects. Making the museum accessible to a wide range of audiences will enrich the church's museum offer, promoting the resources of the historical heritage of the Church in terms of religious, spiritual and educational values.

Keywords: Museum of the Loreto Sisters' Publishing House; Rev. Ignacy Kłopotowski; the Loretan Sisters; Congregation of the Sisters of Our Lady of Loreto 